\title{
Processing and characterization of ultra-thin yttria-stabilized zirconia (YSZ) electrolytic films for SOFC
}

\author{
Yen-Yu Chen, Wen-Cheng J. Wei * \\ Institute of Materials Science and Engineering, National Taiwan University, Taiwan, ROC
}

Received 7 February 2005; received in revised form 19 June 2005; accepted 15 October 2005

\begin{abstract}
Sub-micron yttria-stabilized zirconia (YSZ) electrolyte layer was prepared by a liquid state deposition method and with an average thickness of $0.5 \mu \mathrm{m}$ to improve the performance of the anode-supported solid oxide fuel cell (SOFC). The YSZ precursors, containing yttrium and zirconium species and an additive, poly-vinyl-pyrrolidone (PVP), were spin-coated on a Ni/YSZ anode substrate. Several properties, including crystalline phases, microstructures, and current-voltage $(I-V)$ characteristics, were investigated. The thin film of $4 \mathrm{~mol}_{0} \mathrm{Y}_{2} \mathrm{O}_{3}$-doped $\mathrm{ZrO}_{2}(4 \mathrm{YSZ})$ consisted of cubic, tetragonal, and a trace of monoclinic phases, and showed a crack-free layer after sintering at $1300{ }^{\circ} \mathrm{C}$. The anode supported SOFC, which consists of the Ni-YSZ anode, $4 \mathrm{YSZ}$ electrolyte, and $\mathrm{Pt} / \mathrm{Pd}$ cathode, showed power densities of $477 \mathrm{~mW} / \mathrm{cm}^{2}$ at $600{ }^{\circ} \mathrm{C}$, and 684 $\mathrm{mW} / \mathrm{cm}^{2}$ at $800{ }^{\circ} \mathrm{C}$. Otherwise, the surface cracks of the other YSZ-coated samples (e.g. 8YSZ) can be repaired by a multi-coating method. (C) 2005 Elsevier B.V. All rights reserved.
\end{abstract}

PACS: 73.50.Yg; 73.61.-r

Keywords: YSZ; Thin film; SOFC; Power density

\section{Introduction}

The original design of a single cell of SOFC was an electrolyte support structure with cathode and anode on opposite sides. However, due to a high internal ohmic resistance of the electrolyte, the ionic conductivity decreases with decrease in the operating temperature [1]. The operating temperature of the electrolyte-supported SOFC was limited to $800-1000{ }^{\circ} \mathrm{C}$. Therefore, the electrolyte layer is one of the key components to reach the aims of reducing the operating temperature and increasing cell efficiency. Besides the substitution of the $\mathrm{ZrO}_{2}$-based electrolyte by higher conductive materials, thickness reduction of the electrolyte is an effective approach to reduce the polarization effects of the layer. Anode support concept has been adopted in order to significantly reduce the thickness of the electrolyte to $30 \mu \mathrm{m}$ or less [2]. An example was reported by Weber and IversTiffée [3],that a supported FC theoretically exhibited a

\footnotetext{
* Corresponding author. 1, Roosevelt Road Sec. 4, Taipei, Taiwan 106, ROC. Tel.: +886223632684, +886223634562.

E-mail address: wjwei@ntu.edu.tw (W.-C.J. Wei).
}

minimum operating temperature as low as $500{ }^{\circ} \mathrm{C}$, when the thickness of the electrolyte was less than $1 \mu \mathrm{m}$ [3].

The methods of preparing an anode support SOFC can be classified into three categories. One is the vapor-phase deposition, such as physical or chemical vapor deposition, spray pyrolysis, etc. Another is the liquid-phase deposition, such as the sol-gel and liquid-state deposition methods. The other is the particle deposition/consolidation ${ }^{1}$ method, such as tape casting, screen printing methods, etc. [4]. The vaporphase deposition methods have high potential to prepare a thin electrolyte with a thickness around or under micrometer scale, but the major disadvantage is the high cost of the processing equipment. In contrast, the particle deposition/ consolidation methods are popular and inexpensive among these methods. However, concerning the issue of thickness reduction, the minimum scale of the layers produced by these methods are several micrometers in state-of-the-art. Among these methods, the liquid-phase deposition method shows several advantages in thin film processing. The methods are relatively inexpensive, and also suitable for preparing a multi-

\footnotetext{
${ }^{1}$ It is also named "thick film printing".
} 
compositional system to achieve a mixture of the molecularstate. Therefore, the sintering temperature can be lower than that of any powder deposition method.

The major disadvantage of this method is the strain induced during drying or sintering, which may result in some processing defects, such as cracks, pores, or delamination. One feasible way of overcoming these problems is by a multicoating process $[5,6]$, which repairs the crack step-by-step after cycling coating. However, the permeability decreases with increase in the thickness.

We have adopted a liquid-phase deposition route to deposit a sub-micron YSZ electrolyte layer. Various YSZ liquid precursors with an additive, poly-vinyl-pyrrolidone (PVP), were prepared and spin-coated on a porous $\mathrm{NiO} / \mathrm{YSZ}$ substrate. Besides, the polymerizing agent, poly-vinyl-pyrrolidone (PVP), was utilized in the previous works as well as the literature $[7,8]$, and had successfully overcome the cracking problems of oxide-coated layer. Therefore, in considering the requirements of the gastight electrolyte layer for SOFC, several attempts, such as using a multi-coating method, adding polymerizing agents in the formula [5-7], were used in this study to overcome the problems.

\section{Experimental}

\subsection{Sample preparation}

Zirconium chloride hydroxide $\left(\mathrm{ZrOCl}_{2} \cdot 8 \mathrm{H}_{2} \mathrm{O}, \mathrm{NTHU}\right.$, China), and yttrium chloride hydroxide $\left(\mathrm{YCl}_{6} \cdot 6 \mathrm{H}_{2} \mathrm{O}\right.$, Acros Co., USA) were used as the sources of yttria and zirconia, respectively. De-ionized water was the medium, and the additive, PVP (Acros Co., USA), was used as the polymerizing agent. The compositions of precursors are listed in Table 1. The ratio of yttria species to the total oxide species $\left(\mathrm{Y}_{2} \mathrm{O}_{3}+\mathrm{ZrO}_{2}\right)$ was varied from 4 to $10 \mathrm{~mol} \%$. The mole ratio of a monomer of PVP to the total oxide species was kept at unity. The molar concentrations of total YSZ species in this work was selected between 0.5 and 1.5. After it is fully dissolved, the precursor sols were spin-coated on a porous $\mathrm{NiO} / \mathrm{YSZ}$ substrate, and dried at ambient temperature for 1 day.

The NiO/YSZ substrates were prepared by the tape casting method [9] and the thickness of the tape was around $500 \mu \mathrm{m}$.

Table 1

Formulation of YSZ precursors in this study

\begin{tabular}{lllll}
\hline Sample no. & Chemicals & & & \\
\cline { 2 - 5 } & $\begin{array}{l}\mathrm{ZrOCl}_{2} \cdot 8 \mathrm{H}_{2} \mathrm{O} \\
(\mathrm{mol})\end{array}$ & $\begin{array}{l}\mathrm{YCl}_{3} \cdot 6 \mathrm{H}_{2} \mathrm{O} \\
(\mathrm{mol})\end{array}$ & $\begin{array}{l}\mathrm{VP} \\
(\mathrm{mol})\end{array}$ & $\begin{array}{l}\text { DI-water } \\
(\mathrm{mol})\end{array}$ \\
\hline 4YSZ-05 & 0.480 & 0.040 & 0.50 & 50 \\
4YSZ-11 & 1.056 & 0.088 & 1.10 & 50 \\
4YSZ-14 & 1.344 & 0.112 & 1.40 & 50 \\
4YSZ-15 & 1.440 & 0.120 & 1.50 & 50 \\
6YSZ-11 & 1.034 & 0.132 & 1.10 & 50 \\
8YSZ-11 & 1.012 & 0.176 & 1.10 & 50 \\
10YSZ-11 & 0.990 & 0.220 & 1.10 & 50 \\
\hline
\end{tabular}
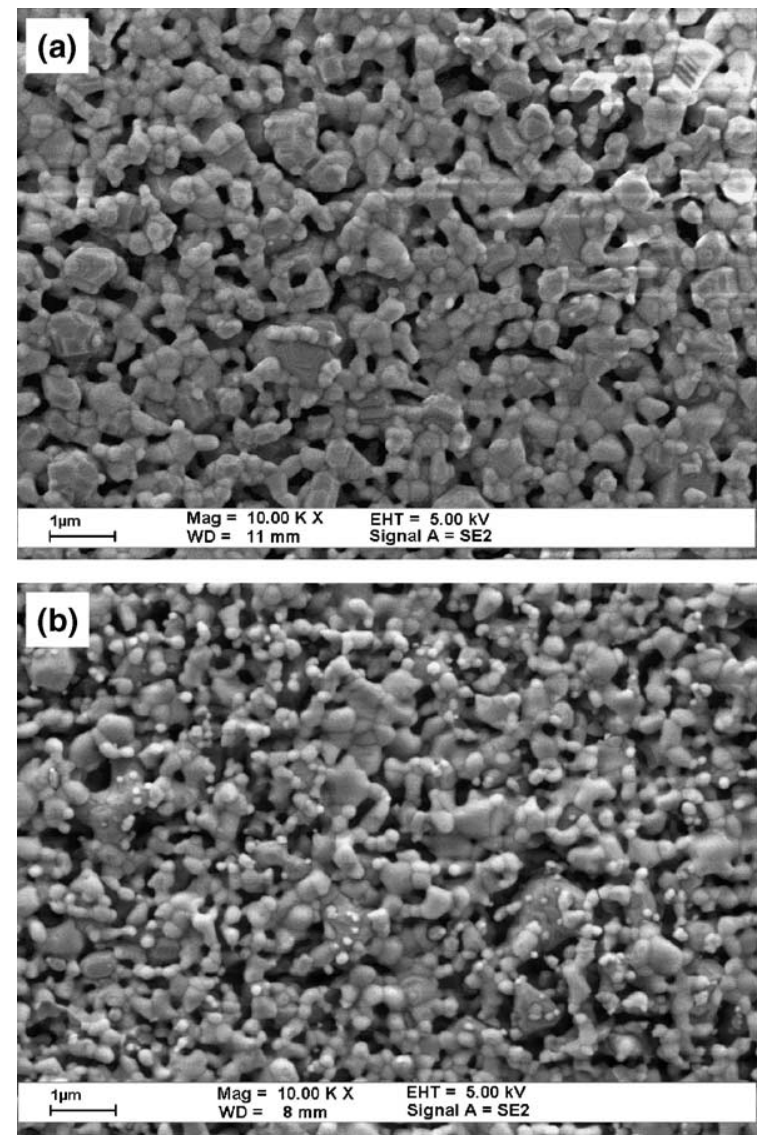

Fig. 1. SEM micrographs of the top view of $\mathrm{NiO} / \mathrm{YSZ}$ tapes: (a) as-sintered at $1300{ }^{\circ} \mathrm{C}$ for $1 \mathrm{~h}$ and (b) after reduction at $800{ }^{\circ} \mathrm{C}$ for $5 \mathrm{~h}$.

After drying, the samples were sintered at $1300{ }^{\circ} \mathrm{C}$ for $1 \mathrm{~h}$ at a heating rate of $10{ }^{\circ} \mathrm{C} / \mathrm{min}$. Later, the sample for cell testing was reduced by $5 \% \mathrm{H}_{2}$ atmosphere at $800{ }^{\circ} \mathrm{C}$ for $5 \mathrm{~h}$ in advance to ensure the formation of $\mathrm{Ni}$ metal in the anode tape.

\subsection{Characterization}

The crystalline phases were analyzed by X-ray diffractometry (XRD, Philips PW1830, Philips Instrument Co., The Netherlands). The sintered samples for XRD analysis were pulverized first before analysis. The microstructure and elemental distribution were observed by scanning electron

Table 2

Comparison of the properties of anode-supported substrates

\begin{tabular}{|c|c|c|}
\hline Property & This study ${ }^{a}$ & $\begin{array}{l}\text { Current status } \\
{[1,10-12]}\end{array}$ \\
\hline Composition & $\begin{array}{l}40 \text { vol. } \% \mathrm{Ni} \\
\mathrm{Ni} / \mathrm{YSZ} \text { cermet }\end{array}$ & $\mathrm{Ni} / \mathrm{YSZ}$ cerme \\
\hline By process & Tape casting & $\begin{array}{l}\text { Tape casting } \\
\text { or die pressing }\end{array}$ \\
\hline Porosity & 31.5 vol. $\%$ & $20-40$ vol. $\%$ \\
\hline $\mathrm{CTE}\left(\mathrm{cm} / \mathrm{cm}{ }^{\circ} \mathrm{C}\right)$ & $12.7 \times 10^{-6}$ & $12.5 \times 10^{-6}$ \\
\hline Conductivity & $1321 \mathrm{~S} / \mathrm{cm}\left(800^{\circ} \mathrm{C}\right)$ & $>100 \mathrm{~S} / \mathrm{cm}$ \\
\hline
\end{tabular}

${ }^{\text {a }}$ Sintered at $1300{ }^{\circ} \mathrm{C}$ and reduced at $800{ }^{\circ} \mathrm{C}$ for $5 \mathrm{~h}$. 


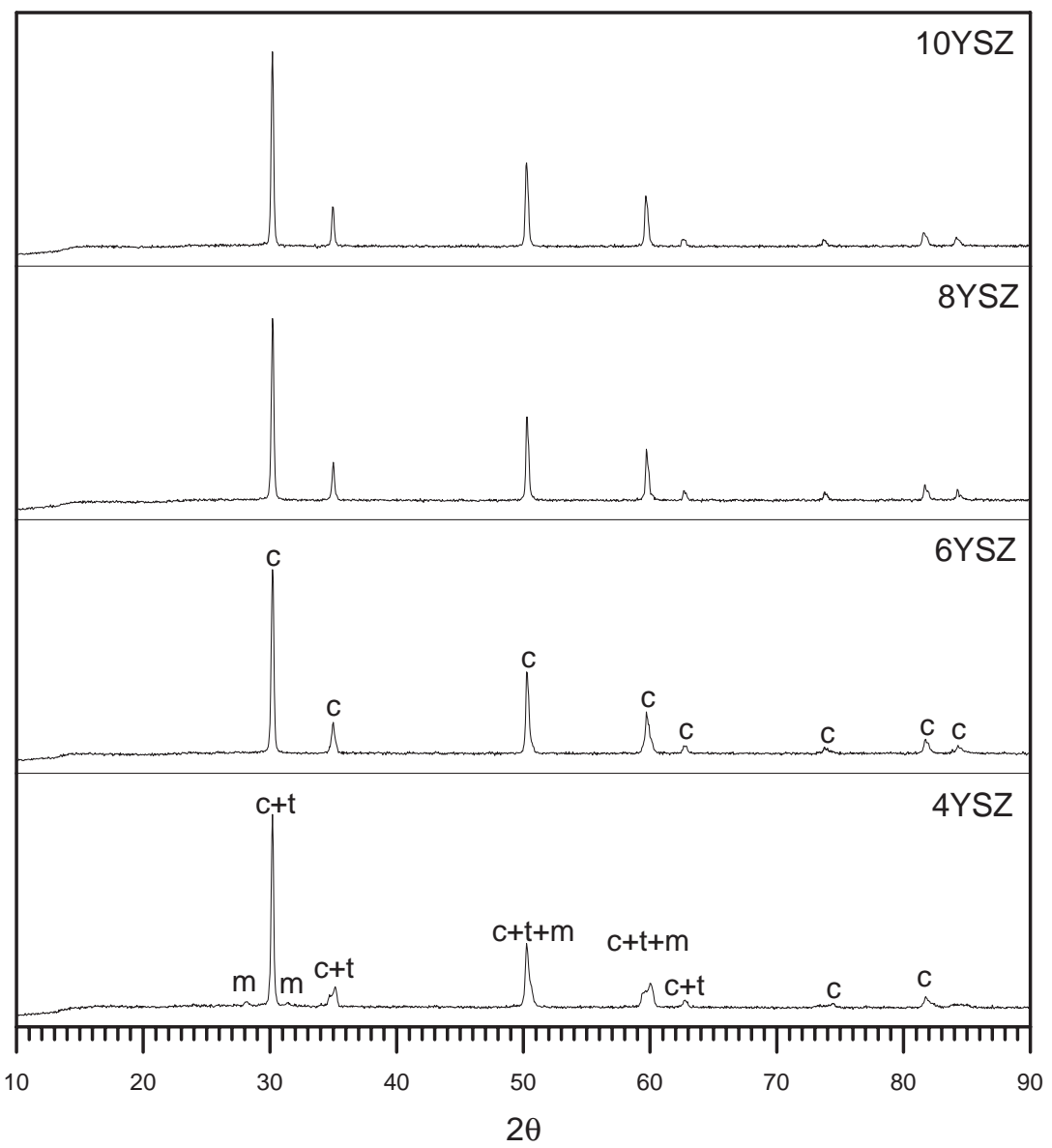

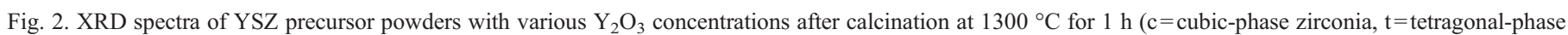
zirconia, and $\mathrm{m}=$ monoclinic-phase zirconia).
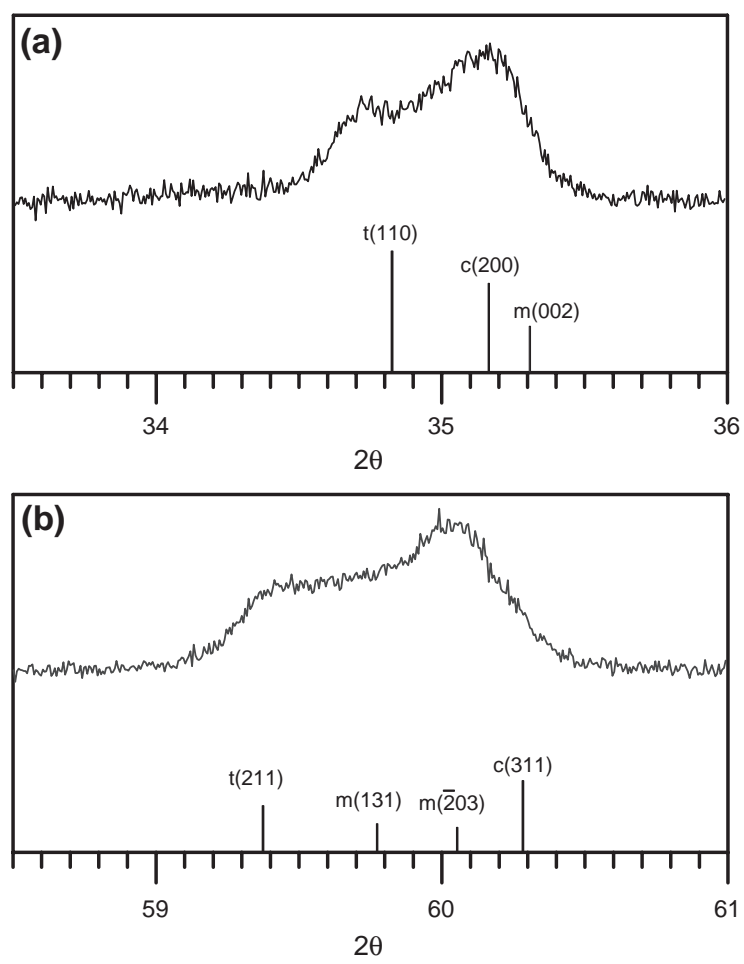

Fig. 3. XRD peaks of $4 \mathrm{YSZ}$ precursor powders at $34^{\circ}-36^{\circ}$ and $59^{\circ}-61^{\circ}$. microscope (SEM, Leo1530, England) equipped with energy dispersive spectroscopy (EDS, EDAX Co., USA). SEM and EDS analysis of the as-sintered samples were carried out. Conductivity measurements for the investigations of $I-V$ behavior and power density of single cell were conducted by using a current source (Model 224, Keithley Instruments Inc., USA), a digital voltmeter (Model 182, Keithley Instrument Inc., USA), and a programmable linear power supply (LPS-305, American Reliance Inc. USA). The sintered dimension of the test sample was $35 \mathrm{~mm} \times 12$ $\mathrm{mm}$. The cathode in an area of $20 \times 10 \mathrm{~mm}^{2}$ for cell testing (Pt/Pd paste) was applied on sample surface by a painting method. For testing cell performance, a fuel gas consisting of $5 \% \quad \mathrm{H}_{2} / 95 \% \quad \mathrm{~N}_{2}$ was used in one chamber and air (oxidant) was used in the other chamber. It may be noted

Table 3

Measured $\mathrm{Y}_{2} \mathrm{O}_{3}$ concentration and crystalline phases of the coated YSZ by quantitative EDS and XRD methods

\begin{tabular}{lll}
\hline Sample no. & Concentration of $\mathrm{Y}_{2} \mathrm{O}_{3}(\mathrm{~mol} \%)$ & Crystalline phase \\
\hline $4 \mathrm{YSZ}$ & $4.02 \pm 0.06$ & $\begin{array}{l}\text { Cubic, tetragonal, } \\
\text { monoclinic }\end{array}$ \\
$6 \mathrm{YSZ}$ & $6.16 \pm 0.11$ & Cubic \\
$8 \mathrm{YSZ}$ & $7.95 \pm 0.01$ & Cubic \\
$10 \mathrm{YSZ}$ & $9.99 \pm 0.08$ & Cubic \\
\hline
\end{tabular}



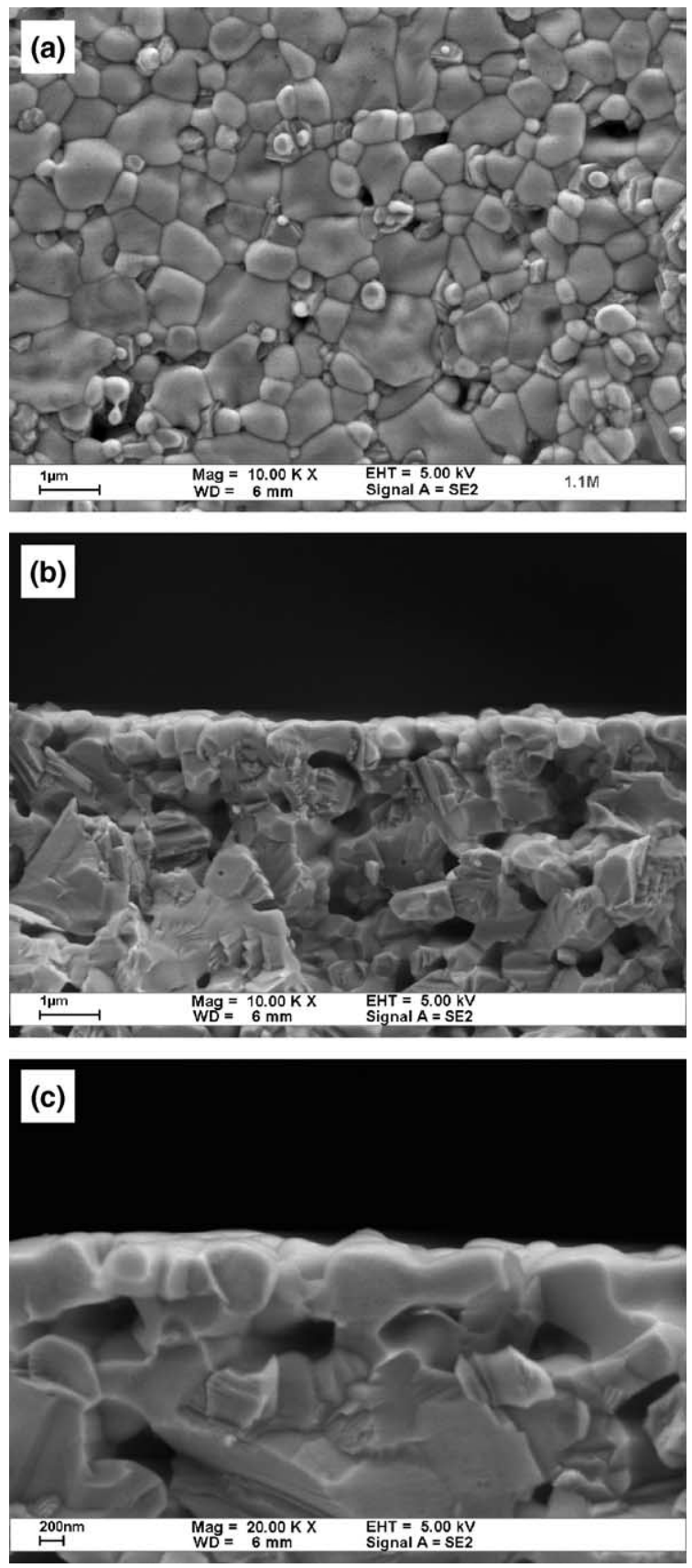

Fig. 4. SEM micrographs of 4 YSZ-11 coated sample after sintering at $1300{ }^{\circ} \mathrm{C}$ for $1 \mathrm{~h}$ : (a) top-view, (b) cross-section, and (c) high magnification of the crosssection.

that for safety consideration only $5 \% \mathrm{H}_{2}$ was used in the fuel gas.

The microstructures of the anode tape after sintering and reduction are shown in Fig. 1. The content of Ni phase in the anode was fixed at 40 vol.\% and appeared porous in structure, which was in the range specified in literature [1,10-12]. In addition, the coefficient of thermal expansion (CTE) of the anode was measured by a thermal mechanical analyzer (TMA, Setsys TMA 16/18, Setram Co., France). The porosity of the anode was measured and calculated by Archimedes' method. Table 2 summarizes and compares these anode properties with those in the literature. The properties of the fabricated anode
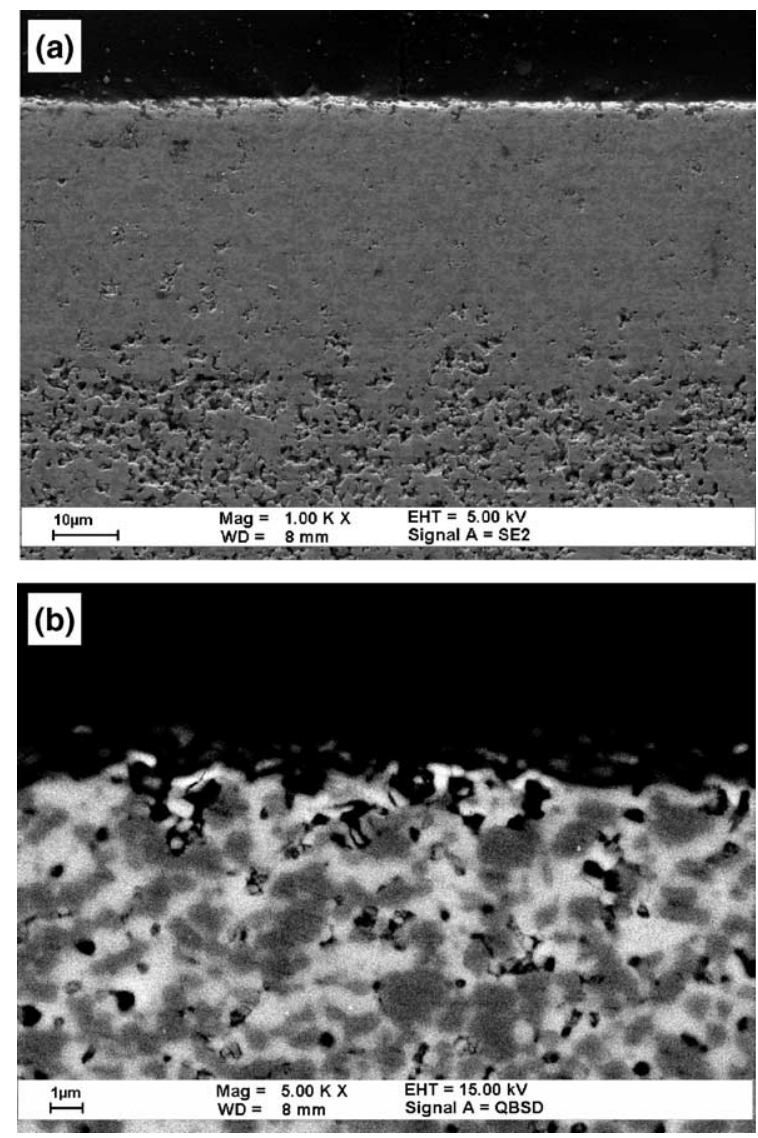

Fig. 5. SEM micrographs of a 4YSZ-05 coated sample after sintering at 1300 ${ }^{\circ} \mathrm{C}$ : (a) cross-section by SE image and (b) BSE image of the top area.

tape in this study fulfilled the requirements of an anodesupported SOFC $[10,12]$.

\section{Results and discussion}

\subsection{Crystalline phase formation of YSZ}

The concentration of doped $\mathrm{Y}_{2} \mathrm{O}_{3}$ is one of the factors influencing the properties of YSZ materials, especially the electric conductivity [13]. The concentrations of doped yttria adopted in this study were in the range of $4-10 \mathrm{~mol} \%$. Fig. 2

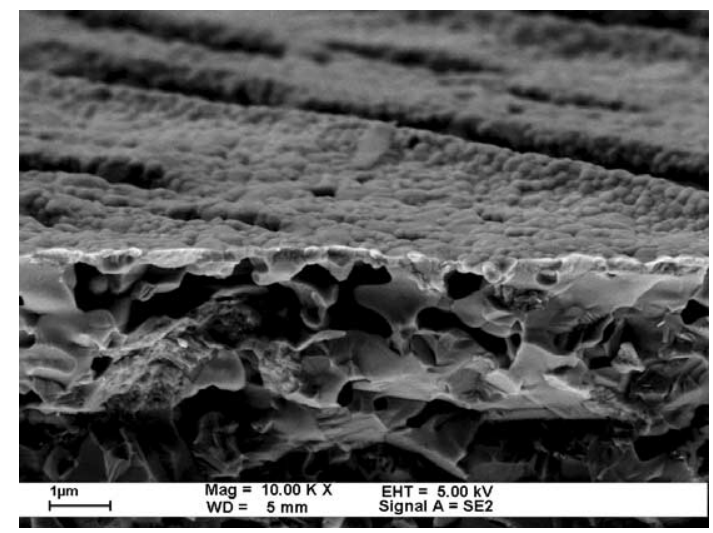

Fig. 6. SEM micrograph of 4YSZ-15 coated sample after heat treatment at $1300{ }^{\circ} \mathrm{C}$ 

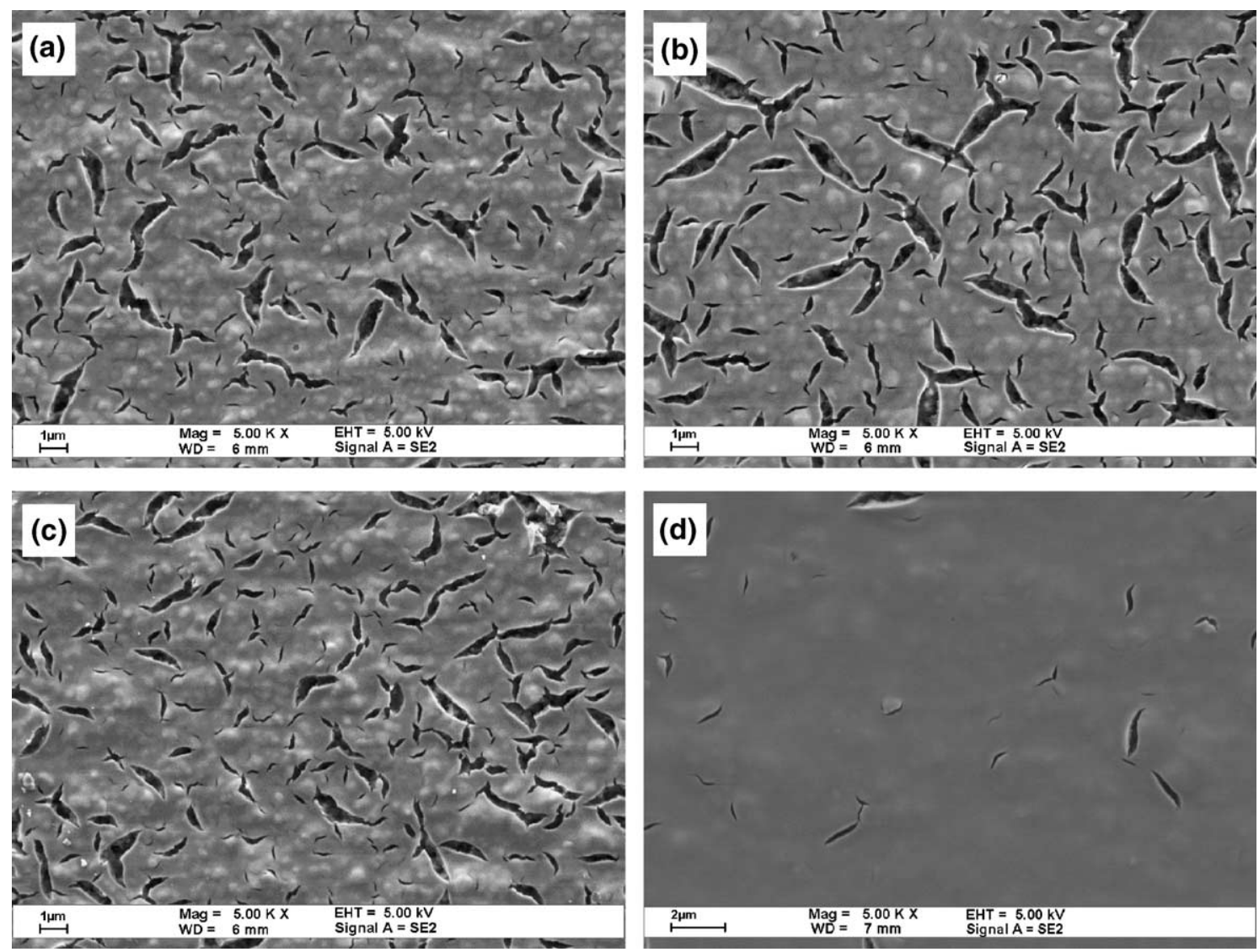

Fig. 7. SEM micrographs of the top-view of various YSZ-coated samples doped with different concentrations of yttria after heat treatment at $600{ }^{\circ} \mathrm{C}$ : (a) $6 \mathrm{YSZ}-11$, (b) 8YSZ-11, (c) 10YSZ-11 by one coating, and (d) 8YSZ-11 by three coatings.

shows the XRD spectra of the YSZ precursor powders after calcination at $1300^{\circ} \mathrm{C}$. The $6 \mathrm{YSZ}, 8 \mathrm{YSZ}$, and $10 \mathrm{YSZ}$ samples showed only a cubic $\mathrm{ZrO}_{2}$ phase. However, the 4YSZ showed additional tetragonal and monoclinic phases. Fig. 3 shows the detailed XRD spectra in the range $34^{\circ}-36^{\circ}$ and $59^{\circ}-61^{\circ}$. Compared with the JCPD files ${ }^{2}$ of $\mathrm{ZrO}_{2}$, the broadened and unsymmetrical peaks consisted of $\mathrm{t}(110), \mathrm{c}(200), \mathrm{m}(002)$ in the $2 \theta$ angles of $34^{\circ}-36^{\circ}$ and $\mathrm{t}(211), \mathrm{m}(131), \mathrm{m}(203), \mathrm{c}(222)$ in $59^{\circ}-61^{\circ}$, respectively.

Arachi et al. reported that the phases of YSZ synthesized by chemical precipitation method with 5-6 mol\% yttria doping contained cubic and tetragonal phases [14]. But in this study, the tetragonal phase in the 6YSZ was not found. The disappearance of the tetragonal phase might be due to the difference in $\mathrm{Y}_{2} \mathrm{O}_{3}$ concentration. In order to precisely determine the doping concentration of $\mathrm{Y}_{2} \mathrm{O}_{3}$ in the YSZ samples, a quantitative EDS analysis [15] was conducted. Table 3 shows the results of the $\mathrm{Y}_{2} \mathrm{O}_{3}$ concentration in various $\mathrm{YSZ}$ samples. The concentrations of the $\mathrm{Y}_{2} \mathrm{O}_{3}$ doping are in an acceptable range $( \pm 0.2 \%)$ to the selected concentration in the formula.

This is no doubt about the fact that the major crystal phase of $3 \mathrm{YSZ}$ is tetragonal. The report by Ramamoorthy et al. also summarized the crystal phase of YSZ doped with 3, 4.5 and 6 mol\% $\mathrm{Y}_{2} \mathrm{O}_{3}$ made by chemical precipitation method [16],

\footnotetext{
${ }^{2}$ Refer to the files of cubic (27-0997), tetragonal (42-1164), and monoclinic $\mathrm{ZrO}_{2}$ phases (37-1484)
}

which showed a spectrum of the 4.5YSZ with only the cubic phase. However, the authors indicated that the spectra should be a mixture of cubic and tetragonal phases without providing any evidence. The crystal phase of 6YSZ was pure cubic and the same as the result in this study.

An early report by Kuzjukevics et al. also analyzed the crystal phases of YSZ samples made by the radio frequency plasma method [17]. The 3.9YSZ sample appeared to have tetragonal, cubic and monoclinic phases. The 6.2YSZ showed tetragonal and cubic phases. The results are inconsistent with the present study, in which the crystalline phases consisted of cubic, tetragonal and a trace of monoclinic phases for the 4YSZ sample, and, for the 6YSZ sample, the major phase was cubic with minor tetragonal phase. The difference could be possibly due to the heat treatment period at the sintering temperatures [18]. In other words, the processing conditions for the formation of the crystalline phases have not reached phase equilibrium condition yet.

\subsection{Characteristics of thin YSZ coating}

Fig. 4 shows the microstructure of 4YSZ-11 coating after sintering at $1300{ }^{\circ} \mathrm{C}$. The top-view of the coating (Fig. 4(a)) shows dense features with a few pores. The average grain size is $0.6 \mu \mathrm{m}$. From the microstructure of the cross-sections in Fig. 4(b) and (c), a thin layer of dense 4YSZ can be seen on the surface of the sample. Due to the illegible interface between the 
coated layer and the substrate, the thickness of the coated layer was estimated to be roughly $0.5 \mu \mathrm{m}$. It may be noted that the coated layer of $4 \mathrm{YSZ}$ is composed of only one monolayer of grains in thickness direction. A few pin-holes were observed on the surface on the coated sample. The density of the pin-holes was only about $1-2 \%$. The permeability of the coated layers by the liquid deposition method is reported to be orders of magnitude less than that of the raw porous substrates [6].

When the concentration of the precursor is lower, the microstructure of the deposited layer changes. Fig. 5 shows the microstructures of the cross-section of a YSZ-coated sample from 4YSZ-05 precursor solution. A dense layer with an average thickness of $35 \mu \mathrm{m}$ was identified on the surface and next to the porous substrate. A back-scattering electron (BSE) image (Fig. 5(b)) showed that this layer consisted of two kinds of grains. The dark gray regions belongs to the $\mathrm{NiO}$ phase, and the light gray ones were the $\mathrm{ZrO}_{2}$ phase indexed by EDS. The formation of the dense diphasic layer might be due to the viscosity of the YSZ precursor, which showed a lower viscosity and resulted in the absorption of the precursor into the surface of the anode substrate by capillary force during spin-coating. When the concentration of the precursor was higher than 1.5 $\mathrm{M}$, the morphology of the coated sample becomes too porous, as shown in Fig. 6. The coated layer was around hundreds nanometers in thickness, but with significant porosity and serious cracking.

Another work in this study was changing the concentration of yttria doping. Fig. 7 shows the microstructures of the top view of those YSZ-coated samples after heat treatment at 600 ${ }^{\circ} \mathrm{C}$. The coated samples showed some micro-cracks and were similar in morphology. Compared with the 4YSZ-coated sample, the tendency of these samples to form cracks is possibly due to the high concentration of doping yttria. When the concentration of yttria doping was higher than $6 \mathrm{~mol} \%$, micro-cracks were found on the coated layer (Fig. 7(a)-(c)). One way of solving this problem is by using a multi-coating method. The microstructure of an 8YSZ sample with three coatings is showed in Fig. 7(d). The cracks were almost sealed and repaired by multi-coating.

Previous XRD results showed that the crystallographic phase of 4YSZ contained additional tetragonal phase apart from that of 6YSZ. A possible reason for the crack-free 4YSZ-coated sample is due to the transformation toughening of t-phase [19]. The cracking of the coated layers is caused by induced thermal stresses. The transformation of $\mathrm{t}-$ to $\mathrm{m}$ phase of YSZ follows the $R$-curve behavior and can enhance the fracture toughness. This toughening effect may prevent the growth of cracks on the 4YSZ-coated layer. Nevertheless, the $6 \mathrm{YSZ}$ or the YSZ samples with a higher doping content of yttria suffer thermal stresses without the toughening.

\subsection{Cell testing}

Among these YSZ-coated samples, a 4YSZ sample from the precursor with intermediate concentration had a thin and dense YSZ layer, which coincided with the requirements of SOFC. Fig. 8 shows the $I-V$ curves and associated power densities of
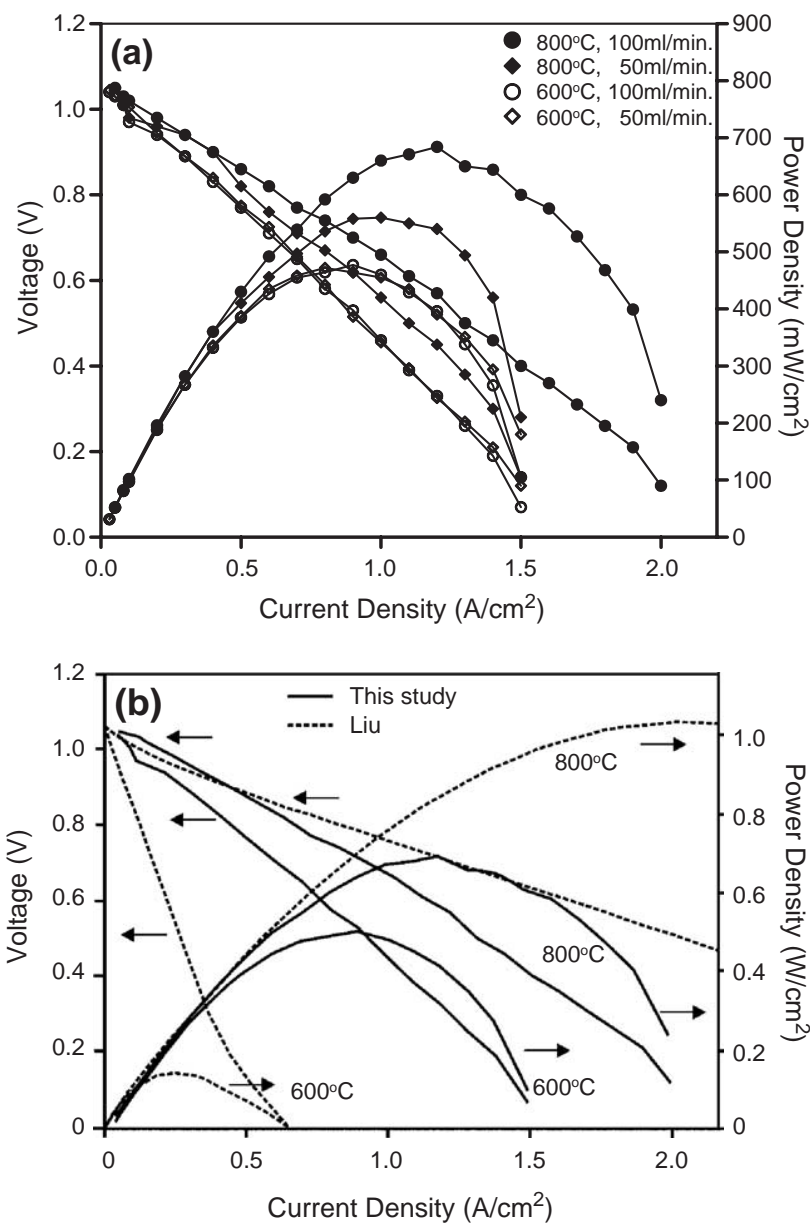

Fig. 8. $I-V$ curves and associated power densities of 4YSZ-11 sample: (a) testing at $600{ }^{\circ} \mathrm{C}$ and $800{ }^{\circ} \mathrm{C}$ with flow rate of 50 and $100 \mathrm{ml} / \mathrm{min}$ and (b) comparison with an SOFC with a $25-\mu \mathrm{m}$ YSZ electrolyte [22]

a single 4YSZ-11 cell as a function of the current density. The decrease in cell voltage is consistent with the ohmic resistance behavior [10]. The results at $600{ }^{\circ} \mathrm{C}$ showed that the curves were not significantly by different at various flow rates, but the peak power density was greater at higher fuel flow rate at 800 ${ }^{\circ} \mathrm{C}$. The highest power densities at $600{ }^{\circ} \mathrm{C}$ and $800{ }^{\circ} \mathrm{C}$ were 477 $\mathrm{mW} / \mathrm{cm}^{2}$ and $684 \mathrm{~mW} / \mathrm{cm}^{2}$, respectively.

The $\mathrm{Y}_{2} \mathrm{O}_{3}$ content of $\mathrm{YSZ}$ with the highest conductivity was reported in the range of $8-10 \mathrm{~mol} \%$ at $1000{ }^{\circ} \mathrm{C}$ $[1,14,20]$. However, Ramamoorthy et al. [16] showed that the conductivity of the YSZ with a doping content of 3-4.5 $\mathrm{mol} \%$ and $9 \mathrm{~mol} \% \mathrm{Y}_{2} \mathrm{O}_{3}$ were of the same order of magnitude at $300{ }^{\circ} \mathrm{C}$ and $500{ }^{\circ} \mathrm{C}$, respectively. The conductivity of 4YSZ layer tested in this study was in the order of $10^{-4} \mathrm{~S} / \mathrm{cm}$ at $600{ }^{\circ} \mathrm{C}$, which was still lower than the conductivity of $3 \mathrm{YSZ}[20]\left(>10^{-3} \mathrm{~S} / \mathrm{cm}\right)$ at $600{ }^{\circ} \mathrm{C}$. The difference in conductivity is probably due to the additional contact resistance at the interface of the YSZ electrolyte and electrodes, as well as the interface of the current collector and the electrodes. The analysis results reported by Leng et al. are similar in the evaluation of an anode-supported SOFC [21].

A performance comparison of this study with a $4 \mathrm{YSZ}$ electrolyte to a cell [22] with a $25-\mu \mathrm{m}$-thick $8 \mathrm{YSZ}$ electrolyte is 
shown in Fig. 8(b). The performance of the 4YSZ sample is lower than that of the $8 \mathrm{YSZ}$ sample at $800{ }^{\circ} \mathrm{C}$. This might be due to the better ionic conduction of the $8 \mathrm{YSZ}$ electrolyte and lower interface resistance at $800^{\circ} \mathrm{C}$. However, the performance $\left(477 \mathrm{~mW} / \mathrm{cm}^{2}\right)$ of the thin-electrolyte SOFC is better than that $\left(<200 \mathrm{~mW} / \mathrm{cm}^{2}\right)$ of the cell with $8 \mathrm{YSZ}$ electrolyte tested at 600 ${ }^{\circ} \mathrm{C}$, despite the fact of low $\mathrm{Y}_{2} \mathrm{O}_{3}$ doping concentration and low conductivity of $4 \mathrm{YSZ}$. The results showed that the reduction of the thickness to sub-micrometer can improve the power density of a single cell at low temperature.

\section{Conclusion}

A typical electrolyte material system of YSZ was adopted and used to prepare an ultra-thin film on a Ni/YSZ anode substrate by a liquid-state deposition method. The crystal phases of 4YSZ samples consisted of cubic, tetragonal, and a trace of monoclinic phases. The samples with a higher Ydoping showed only a cubic phase. Among the coatings, the 4YSZ-coated sample was found the one that is crack-free. The layer showed an average thickness of $0.5 \mu \mathrm{m}$ and an average grain size of $0.6 \mu \mathrm{m}$. Besides, the cracks of Y-doped $\mathrm{ZrO}_{2}-$ coated samples could be sealed by a multi-coating method. The crack-free nature of the 4 YSZ was possibly due to the transformation toughness of t- to m-phase. The results of cell testing of the 4YSZ-coated sample showed the best power density of $477 \mathrm{~mW} / \mathrm{cm}^{2}$ at $600{ }^{\circ} \mathrm{C}$ and $684 \mathrm{~mW} / \mathrm{cm}^{2}$ at $800{ }^{\circ} \mathrm{C}$, respectively.

\section{Acknowledgement}

The authors gratefully acknowledge the financial support provided by the National Science Council (NSC) in Taiwan (grant no. NSC92-2212-E-002-097), and the NSC-DAAD summer program of 2002. The comments given by Prof.
Andreas Roosen and help from his colleagues at the Department of Materials Science, Friedrich-Alexander-University Erlangen-Nuremberg in Germany are greatly appreciated.

\section{References}

[1] N.Q. Minh, J. Am. Ceram. Soc. 76 (1993) 563.

[2] F. Tietz, H.-P. Buchkremer, D. Stover, Solid State Ionics 152-153 (2002) 373.

[3] A. Weber, E. Ivers-Tiffée, J. Power Sources 127 (2004) 273

[4] J. Will, A. Mitterdorfer, C. Kleinlogel, D. Perednis, L.J. Gauckler, Solid State Ionics 131 (2000) 79

[5] C.C. Chen, M.M. Nasrallah, H.U. Anderson, Solid State Ionics 70/71 (1994) 101.

[6] C. Xia, S. Zha, W. Yang, R. Peng, D. Peng, G. Meng, Solid State Ionics $133(2000) 287$.

[7] Y.Y. Chen, W.C.J. Wei, J. Eur. Ceram. Soc. 21 (2001) 2535.

[8] H. Kozuka, M. Kajimura, J. Am. Ceram. Soc. 83 (2000) 1056.

[9] M. Wagner, A. Stiegelschmitt, A. Roosen, Keram. Z. 52 (2000) 490.

[10] Fuel Cell Handbook, 6th ed., EG and G Services Parsons, Inc., 2002, issued by U.S. Department of Energy.

[11] D.-S. Lee, J.-H. Lee, J. Kim, H.-W. Lee, H.S. Song, Solid State Ionics 166 (2004) 13

[12] W.Z. Zhu, S.C. Deevi, Mater. Sci. Eng., A Struct. Mater.: Prop. Microstruct. Process. 362 (2003) 228.

[13] K. Kordesch, G. Simader, Fuel Cells and Their Applications, VCH, Germany, 1996.

[14] Y. Arachi, H. Sakai, O. Yamamoto, Y. Takeda, N. Imanishai, Solid State Ionics 121 (1999) 133.

[15] C.-C.T. Yang, H.J. Cho, W.J. Wei, J. Eur. Ceram. Soc. 22 (2002) 199.

[16] R. Ramamoorthy, D. Sundararaman, S. Ramasamy, Solid State Ionics 123 (1999) 271.

[17] A. Kuzjukevics, S. Linderoth, J. Grabis, Solid State Ionics 92 (1996) 253.

[18] M. Yashima, M. Kakihana, M. Yoshimura, Solid State Ionics 86-88 (1996) 1131.

[19] A.H. Heuer, J. Am. Ceram. Soc. 70 (1987) 689.

[20] M. Filal, C. Petot, M. Mokchah, C. Chateau, J.L. Carpentier, Solid State Ionics 80 (1995) 27.

[21] Y.J. Leng, S.H. Chan, K.A. Khor, S.P. Jiang, Int. J. Hydrogen Energy 29 (2004) 1025.

[22] J. Liu, S. Barnett, J. Am. Ceram. Soc. 85 (2002) 3096. 